\title{
Impact of Nitrogen Fertilizers on Methane Emissions from Flooded Rice
}

\section{SANDEEP K. MALYAN*, ARTI BHATIA, OM KUMAR and RITU TOMER}

\author{
Center for Environment Science and Climate Resilient Agriculture, \\ Indian Agricultural Research Institute, New Delhi-110012, India. \\ ${ }^{*}$ Corresponding author E-mail: sandeepkmalyan@gmail.com
}

http://dx.doi.org/10.12944/CWE.11.3.20

(Received: November 04, 2016; Accepted: December 11, 2016)

\begin{abstract}
Methane is second most potent greenhouse gas emitted under anaerobic condition in rice soils. Effects of different nitrogen fertilizer application on methane emissions in flooded paddy field were studied. The experiment was laid out in a randomized complete block design with three treatments and three replications. The treatments were control $\left(0 \mathrm{~kg} \mathrm{~N} \mathrm{ha}^{-1}\right)$, urea $\left(120 \mathrm{~kg} \mathrm{~N} \mathrm{ha}^{-1}\right)$ and ammonium sulfate $\left(120 \mathrm{~kg} \mathrm{~N} \mathrm{ha}^{-1}\right)$. In all treatments $\mathrm{P}\left(60 \mathrm{~kg} \mathrm{P}_{2} \mathrm{O}_{5} \mathrm{ha}^{-1}\right)$ along with $\mathrm{K}\left(40 \mathrm{~kg} \mathrm{~K}_{2} \mathrm{O} \mathrm{ha}^{-1}\right)$ were also applied as basal dose. The cumulative seasonal methane flux was highest in urea 36.3 $\left(\mathrm{kg} \mathrm{ha}^{-1}\right)$ followed by control $35.2\left(\mathrm{~kg} \mathrm{ha}^{-1}\right)$ and ammonium sulfate $28.5\left(\mathrm{~kg} \mathrm{ha}^{-1}\right)$. Ammonium sulfate application reduced total seasonal emission by $19.5 \%$ as compared to control while it reduced $\mathrm{CH}_{4}$ emissions by $21.6 \%$ as compared to urea application. On the basis of this study we can conclude that application of ammonium sulfate is an effective tool for mitigating methane emissions from rice soils.
\end{abstract}

Keywords: Rice, Methane, Urea, Ammonium sulfate.

\section{INTRODUCTION}

Methane $\left(\mathrm{CH}_{4}\right)$ atmospheric concentration has significantly rises due anthropogenic activity. Graedel and McRae ${ }^{1}$ presented first evidence that atmospheric concentration of $\mathrm{CH}_{4}$ is increasing. In agriculture submerged rice (Oryza sativa L.) soils are the major source of $\mathrm{CH}_{4}$ emission to atmosphere. Rice is second most consumed cereal in world after corn and out of total rice $90 \%$ is cultivated in Asia under irrigated conditions. Under continues standing water soil redox potential (Eh) drops sharply within few days and leads to process methanogenesis in soil' ${ }^{2}$. In methanogensis, soil archaea methanogens degraded organic matter and produce $\mathrm{CH}_{4}{ }^{3} \cdot \mathrm{CH}_{4}$ emission from rice soil is a net balance of production by methanogens in reducing environment after oxidation by methanotrophs in oxidizing environment and it is influenced by several factors such as water conditions, Eh, soil temperature, $\mathrm{pH}$, fertilizer managements, and organic matter ${ }^{4-5}$. Water management's practices such as alternate drying and wetting, mid-season drainage, system of rice intensification etc were effective tools to reduce $\mathrm{CH}_{4}$ emission from rice cultivation. Water management practices have limitation in lowland area where water management is difficult task so there is need for other effective interventions for $\mathrm{CH}_{4}$ reduction from lowland or continues flooded rice soils. $\mathrm{CH}_{4}$ is second most potent greenhouse gas after carbon dioxide and it is 25 times greenhouse with more potent gas as compared to carbon dioxide ${ }^{6-7}$. According to IPCC $\mathrm{CH}_{4}$ contributes $16 \%$ of total emissions at global level and out of total rice field alone contribute $10 \%$ of total $\mathrm{CH}_{4}$ emission at global level ${ }^{9}$. Kumar et $\mathrm{al}^{10}$ reported that by the end of twenty first century global mean temperature may rise up to $1.5^{\circ} \mathrm{C}$ due to increased in global greenhouses gases atmospheric concentrations. Global warming is major concerned of $21^{\text {st }}$ century for scientific and 
policy maker. As the world population was increasing so under such scenario $\mathrm{CH}_{4}$ mitigation from rice field needed without having any negative impact on rice production. Rice production depends on type and amount of nitrogen $(\mathrm{N})$ based fertilizers applied for cultivation. $\mathrm{N}$ based fertilizer amendments may be

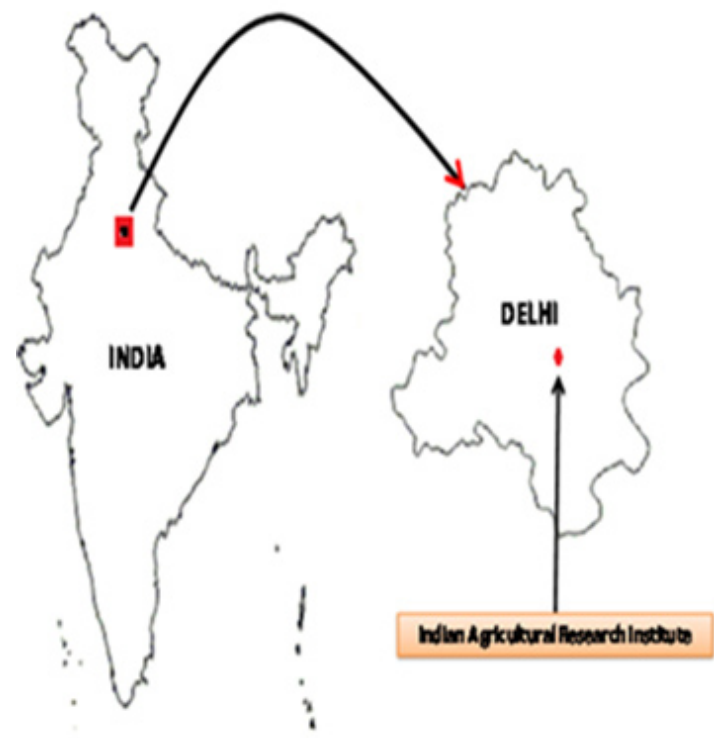

Fig.1: Experimental site of Indian Agricultural Research Institute, New Delhi, India used for $\mathrm{CH}_{4}$ emissions mitigation from the rice soil. Impact of different $\mathrm{N}$ based fertilizer on $\mathrm{CH}_{4}$ emission is less evaluated so it is needed. The objective of this field experiment is to evaluate the impact of nitrogen fertilizer on $\mathrm{CH}_{4}$ emissions from rice soil under continuous flooded condition.

\section{MATERIAL AND METHODS}

\section{Site Descriptions}

Field experiment was carried out at the

Table 1: Pri-transplanting physicochemical properties of the experimental site

\begin{tabular}{|c|c|}
\hline Soil parameter & Value \\
\hline Sand (\%) & 46 \\
\hline Slit (\%) & 32 \\
\hline Clay (\%) & 22 \\
\hline pH (1:2.5 :: soil: water) & 8.4 \\
\hline Organic C (\%) & 0.58 \\
\hline $\mathrm{CEC}^{\star}\left(\mathrm{c} \mathrm{mol} \mathrm{kg}{ }^{-1}\right)$ & 7.3 \\
\hline Hydraulic conductivity $\left(\mathrm{cm} \mathrm{d}^{-1}\right)$ & 4.7 \\
\hline Olsen $\mathrm{P}\left(\mathrm{kg} \mathrm{ha}{ }^{-1}\right)$ & 31.9 \\
\hline $\mathrm{KMnO}_{4}$ extractable $\mathrm{N}\left(\mathrm{kg} \mathrm{ha}^{-1}\right)$ & 250 \\
\hline $\mathrm{NH}_{4}^{+}{ }^{+} \mathrm{N}\left(\mathrm{kg} \mathrm{ha}^{-1}\right)$ & 24.8 \\
\hline $\mathrm{NO}_{3}^{-}-\mathrm{N}\left(\mathrm{kg} \mathrm{ha}^{-1}\right)$ & 34.1 \\
\hline Moisture content at field capacity (\%) & 21.2 \\
\hline
\end{tabular}

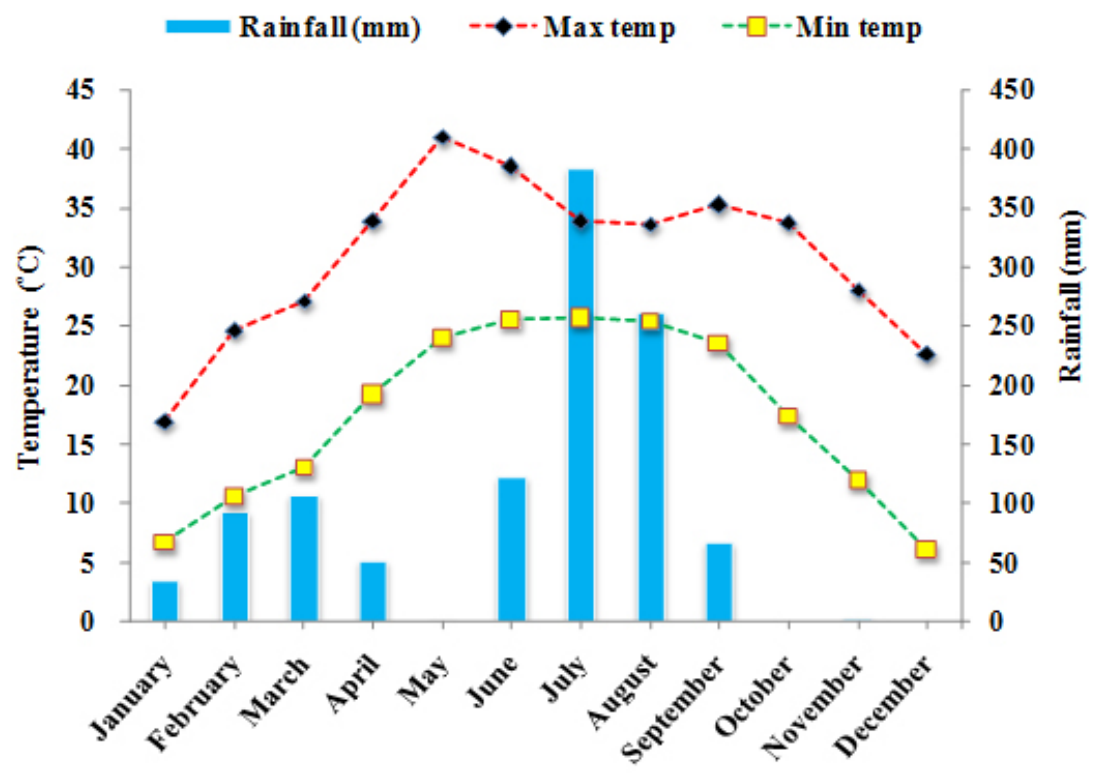

Fig. 2: Metrological data of experimental site 
research farm of Indian Agricultural Research Institute, New Delhi, India, during kharif season of year 2015 (Fig. 1). The climatic condition of the region was sub-tropical, semi arid that was characterized by dry winter and maximum rainfall occurs during from June to September of year (Fig. 2). The soil of study site was sandy loam in texture and pri-transplanting physicochemical properties of experimental site soil are mentioned in Table (1).

\section{Experimental design and treatments details}

The experiments consist of three treatments with three replicate each which are arranged in RBD. Composition and dose of various treatments were mentioned in Table (2). Pusa Basmati 1509 variety of rice (Oryza sativa L.) was adopted for conducting the experiment. Two to three rice seedlings (23 days age) were transplanted at $15 \times 20 \mathrm{~cm}$ spacing. Continuous flooding condition at $8 \pm 4 \mathrm{~cm}$ water level was maintained by groundwater irrigation for entire cropping period. The field was naturally allowed to dry three weeks before harvesting of crop. No chemical interventions (pesticide and herbicide) were applied to avoid their additional effects. Weeding was done manual when required.

Table 2: Different treatments used during rice cultivation

\begin{tabular}{|c|c|c|}
\hline Treatment & Dose & Method of application \\
\hline Control & $\begin{array}{l}\mathrm{N}\left(0 \mathrm{~kg} \mathrm{~N} \mathrm{ha}^{-1}\right) \\
\mathrm{P}\left(0 \mathrm{~kg} \mathrm{P}_{2} \mathrm{O}_{5} \mathrm{ha}^{-1}\right) \\
\mathrm{K}\left(0 \mathrm{~kg} \mathrm{~K}_{2} \mathrm{O} \mathrm{ha}^{-1}\right)\end{array}$ & Not applicable \\
\hline Urea & $\begin{array}{l}\mathrm{N}\left(120 \mathrm{~kg} \mathrm{~N} \mathrm{ha}^{-1}\right) \\
\mathrm{P}\left(60 \mathrm{~kg} \mathrm{P} \mathrm{O}_{5} \mathrm{ha}^{-1}\right) \\
\mathrm{K}\left(40 \mathrm{~kg} \mathrm{~K}_{2} \mathrm{O} \mathrm{ha}^{-1}\right)\end{array}$ & $\begin{array}{l}\mathrm{P} \text { and } \mathrm{K} \text { were applied basally, while } \mathrm{N} \text { (Urea) } \\
\text { applied in three splits in } 50 \% \text { (basal) and, } 25 \% \\
\text { (tillering) and } 25 \% \text { (panicle initiation) of total dose. }\end{array}$ \\
\hline $\begin{array}{l}\text { Ammonium } \\
\text { sulfate (AS) }\end{array}$ & $\begin{array}{l}\text { AS (120 kg N ha-1), } \\
\mathrm{P}\left(60 \mathrm{~kg} \mathrm{P}_{2} \mathrm{O}_{5} \mathrm{ha}^{-1}\right) \\
\mathrm{K}\left(40 \mathrm{~kg} \mathrm{~K}_{2} \mathrm{O} \mathrm{ha} \mathrm{ha}^{-1}\right)\end{array}$ & $\begin{array}{l}\mathrm{P} \text { and } \mathrm{K} \text { were applied basally, while } \mathrm{N} \\
\text { (Ammonium sulfate) applied in three splits in } \\
50 \% \text { (basal) and, } 25 \% \text { (tillering) and } 25 \% \text { (panicle initiation) } \\
\text { of total dose. }\end{array}$ \\
\hline
\end{tabular}

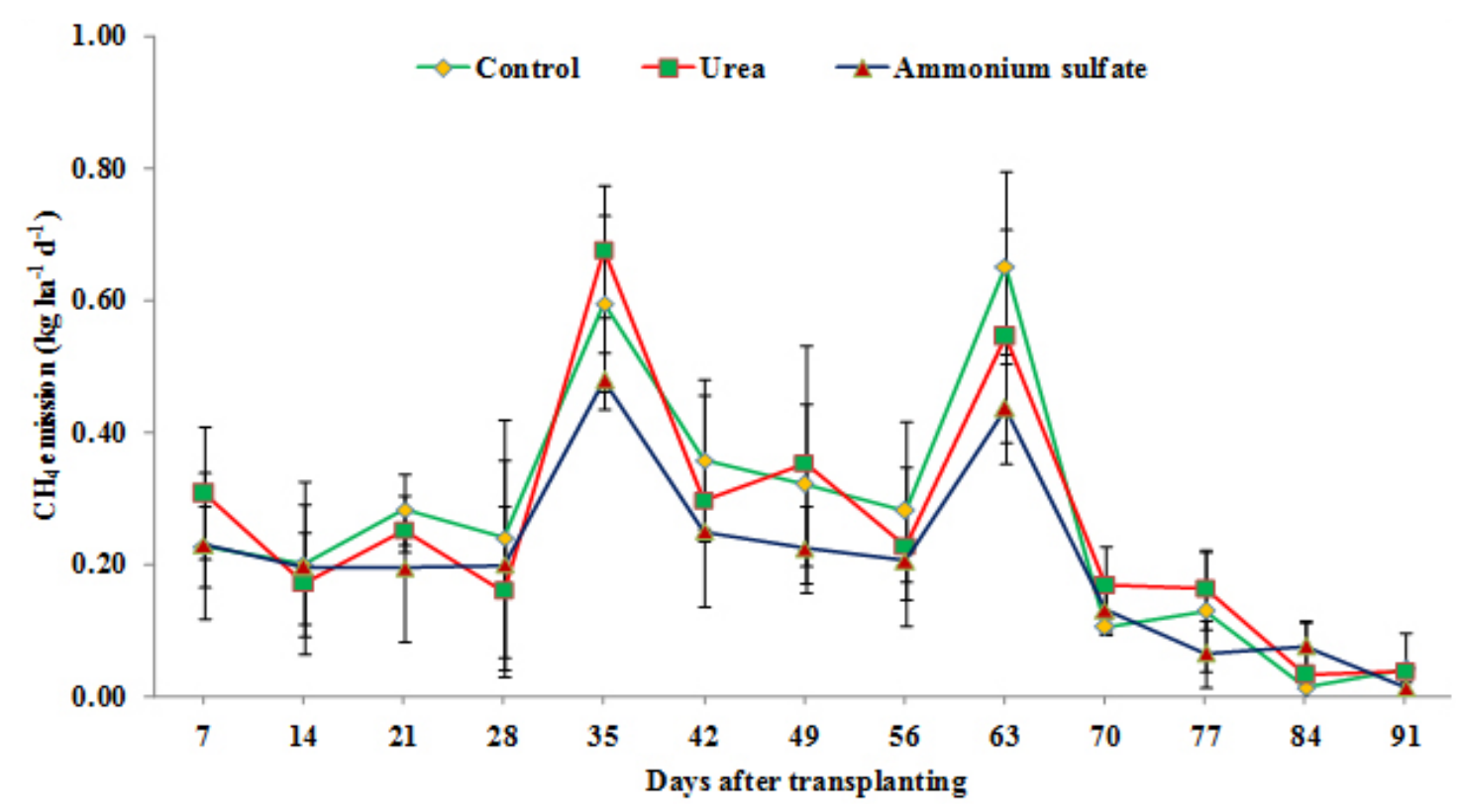

Fig.3: Methane emissions from rice soil under different nitrogen based fertilizer amendments 


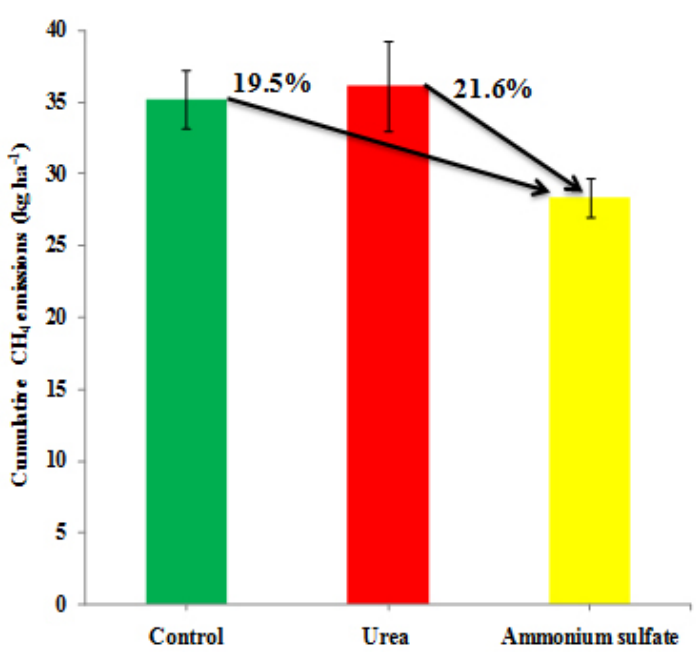

Fig. 4: Cumulative seasonal methane emissions from rice soil along with methane reduction in percentage

\section{Methane sampling collection and analysis}

Gas samples were collected at 7 days regular interval throughout the rice cultivation by manual closed chamber technique ${ }^{11}$. Gas samples were collected between 9 am to 11 am and samples were withdrawn from top of the chamber using $20 \mathrm{ml}$ air-tight syringes at $0,1 / 2$ and $1 \mathrm{hrs}$. Concentration of $\mathrm{CH}_{4}$ gas in the collected gas samples were measured by using gas chromatography equipped with column and a flame ionization detector.

\section{RESULT AND DISCUSSION}

Methane emission among all treatments was low during first three weeks and significantly increased with plant growth and lower soil Eh. The highest flux peak was observed at 35 days after transplanting (DAT) and second peak occur at 63 DAT (Fig 3).

Two higher $\mathrm{CH}_{4}$ peaks may be due to degradation of soil organic matter by methanogens bacteria under anaerobic conditions and similar flux were also reported by ${ }^{12}$ in rice soil. The cumulative seasonal $\mathrm{CH}_{4}$ flux was $35.2 \mathrm{~kg} \mathrm{ha}^{-1}$ under the control treatment The highest cumulative $\mathrm{CH}_{4}$ flux was recorded in urea $\left(36.3 \mathrm{~kg} \mathrm{ha}^{-1}\right)$ treatment followed by control (35.2kg ha-1) and ammonium sulfate $(28.3 \mathrm{~kg}$ $\left.\mathrm{ha}^{-1}\right)$. As compare to control, urea fertilizer application enhances $\mathrm{CH}_{4}$ emissions by $2.72 \%$ and ammonium sulfate amendments reduce $\mathrm{CH}_{4}$ emissions by
$19.5 \%$ as compared to control (Fig. 4). Ammonium sulfate application reduced the total seasonal $\mathrm{CH}_{4}$ emissions by $21.6 \%$ over urea (Fig. 4 ).

The higher $\mathrm{CH}_{4}$ emission under nitrogen applied plots over no nitrogen amendments has been reported ${ }^{13}$. Urea application enhances the ammonium ions concentration in soil and due to structural symmetry between $\mathrm{CH}_{4}$ and ammonium ion $^{3}$ methanotrophs bind with ammonium ions instead of $\mathrm{CH}_{4}$ therefore results in less $\mathrm{CH}_{4}$ oxidation by methanotrophs in soil which finally result in higher $\mathrm{CH}_{4}$ emission from soil ${ }^{14}$.

Minami ${ }^{15}$ observed about more than $15 \%$ reduction in average $\mathrm{CH}_{4}$ flux from rice soil by incorporated with ammonium sulfate at 200 $\mathrm{kg} \mathrm{N} \mathrm{ha}^{-1}$ rate as compared to $200 \mathrm{~kg} \mathrm{~N} \mathrm{ha}^{-1}$ urea incorporation. Similar finding were also observed by Ali et $a^{16}$ and they reported $16 \%$ and $21 \%$ reduction in total seasonal $\mathrm{CH}_{4}$ flux by ammonium sulfate over urea in upland and lowland rice soil in Bangladesh respectively. On addition of ammonium sulfate in soil concentration of active sulfate ions was increased ${ }^{16}$ which result in higher population of sulfate reducing bacteria in soil. Sulfate reducing bacteria compete with methanogens bacteria for organic matter as they both feed on similar substrate ${ }^{5}$ therefore on application of ammonium sulfate suppressed methanogens activity in soil which result in $\mathrm{CH}_{4}$ flux reduction form rice soil.

\section{CONCLUSIONS}

In this field study we evaluate the impact different nitrogen based fertilizer on methane emission from rice soil. A total cumulative methane emissions was highest in urea applied plots and lowest in ammonium sulfate plots. Ammonium sulfate application reduces $19.5 \%$ and $21.6 \%$ as compare to urea and control respectively. Therefore, based on this study it could be suggested that application of ammonium sulfate significantly reduce methane emission from rice soils.

\section{ACKNOWLEDGEMENTS}

We thank the Director, Dean and PG School of Indian Agricultural Research Institute (IARI), New Delhi for providing all facilities required in this study. 
Financial support to Mr. Sandeep K. Malyan during Ph.D as UGC-JRF/SRF provided by University Grant
Commission (UGC), New Delhi Government of India is gratefully acknowledged.

\section{REFERENCES}

1. Graedel, T.E., McRae, J.E., On the possible increase of the atmospheric methane and carbon monoxide concentrations during the last decade. Geophys. Res. Lett. 7, 977-979 (1980).

2. Kumar, S.S., Malyan, S.K., Nitrification Inhibitors: A Perspective tool to Mitigate Greenhouse Gas Emission from Rice Soils. Curr. World Environ. 11(2), 423-428 (2016).

3. Malyan, S.K., Bhatia, A., Kumar, A., Gupta, D.K., Singh, R., Kumar, S.S., Tomer, R., Kumar, O., Jain, N., Methane production, oxidation and mitigation: A mechanistic understanding and comprehensive evaluation of influencing factors. Sci. Total Environ. 1, 874-896 (2016).

4. Gupta, D.K., Bhatia, A., Kumar, A., Das, T.K., Jain, N., Tomer, R., Malyan, S.K., Fagodiya, R.K., Dubey, R., Pathak, H., Mitigation of greenhouse gas emission from rice-wheat system of the Indo-Gangetic plains: Through tillage, irrigation and fertilizer management. Agric. Ecosyst. Environ. 230, 1-9 (2016).

5. Hussain, S., Peng, S., Fahad, S., Khaliq, A., Huang, J., Cui, K., Nie, L., Rice management interventions to mitigate greenhouse gas emissions: a review. Environ. Sci. Pollut. Res. 22, 3342-3360 (2015).

6. Pramanik, P., Kim, P.J., Contrasting effects EDTA applications on the fluxes of methane and nitrous oxide emissions from strawtreated rice paddy soils. J. Sci. Food Agric. n/a-n/a. doi:10.1002/jsfa.7727 (2016).

7. Bhatia, A., Ghosh, A., Kumar, V., Tomer, R., Singh, S.D., Pathak, H., Effect of elevated tropospheric ozone on methane and nitrous oxide emission from rice soil in north India. Agric. Ecosyst. Environ. 144, 21-28 (2011).

8. International Panel on Climate Change, Climate Change, Mitigation of Climate Change. Contribution of Working Group III to the Fifth Assessment Report of the Intergovernmental Panel on Climate Change
[Edenhofer, O., R. Pichs-Madruga, Y. Sokona, E. Farahani, S. Kadner, K.Seyboth, A. Adler, I. Baum, S. Brunner, P. Eickemeier, B. Kriemann, J. Savolainen, S. Schlömer, C. von Stechow, T. Zwickel and J.C. Minx (eds.)]. Cambridge University Press, Cambridge, United Kingdom and New York, NY, USA (2014).

9. Global Methane Initiative. Global methane emissions and mitigation opportunities. GMI, [Online] Available: www.globalmethane. org (August 17, 2011) (2011).

10. Kumar, R., Mina, U., Gogoi, R., Bhatia, A., Harit, R.C., Effect of elevated temperature and carbon dioxide levels on maydis leaf blight disease tolerance attributes in maize. Agric. Ecosyst. Environ. 231, 98-104 (2016).

11. Hutchinson, G.L, Mosier, A.R., Improved Soil Cover Method for Field Measurement of Nitrous Oxide Fluxes. Soil Sci. Soc. Am. J. 45, 311-316 (1981).

12. Suryavanshi, P., Singh, Y. V., Prasanna, R., Bhatia, A., Shivay, Y.S., Pattern of methane emission and water productivity under different methods of rice crop establishment. Paddy Water Environ. 11, 321-329 (2013).

13. Xia L, Wang S, Yan X, Effects of long-term straw incorporation on the net global warming potential and the net economic benefit in a rice-wheat cropping system in China. Agric. Ecosyst. Environ. 197: 118-127 (2014).

14. Schimel, J., Rice, microbes and methane. Nature 403, 375, 377 (2000).

15. Minami, K., The effect of nitrogen fertilizer use and other practices on methane emission from flooded rice. Fertil. Res. 40, 71-84 (1995).

16. Ali, M.A., Farouque, M.G., Haque, M., Kabir, A.U., Influence of soil amendments on mitigating methane emissions and sustaining rice productivity in paddy soil ecosystems of Bangladesh. J. Environ. Sci. Nat. Resour. 5, 179-185 (2012). 